\title{
Comparative phylogeny of rrs and nifH genes in the Bacillaceae
}

\author{
Wafa Achouak, ${ }^{1}$ Philippe Normand ${ }^{2}$ and Thierry Heulin ${ }^{1}$ \\ Author for correspondence: Thierry Heulin. Tel: +33442254827 . Fax: +33442256648 \\ e-mail: theulin@cea.fr
}

\footnotetext{
1 CEA/Cadarache, DSV-DEVM, Laboratoire d'Ecologie Microbienne de la Rhizosphère, UMR 163 CNRS-CEA, F-13108 Saint Paul lez Durance, France

2 Laboratoire d'Ecologie Microbienne du Sol, UMR 5557 CNRS and DTAMB Université $C$. Bernard Lyon I, 43, bd du 11 novembre 1918, F-69622 Villeurbanne Cedex, France
}

\begin{abstract}
The rrs (16S rDNA) gene sequences of nitrogen-fixing endospore-forming bacilli isolated from the rhizosphere of wheat and maize were determined in order to infer their phylogenetic position in the Bacillaceae. These rhizosphere strains form a monophyletic cluster with Paenibacillus azotofixans, Paenibacillus polymyxa and Paenibacillus macerans. Two of them (RSA19 and TOD45) had previously been identified as Bacillus circulans (group 2) by phenotypic characterization (API 50CH). Evidence for nitrogen fixation by $P$. azotofixans, P. polymyxa, P. macerans and putative B. circulans strains RSA19 and TOD45 was provided by acetylene-reduction activity, and confirmed by amplifying and sequencing a nifH fragment ( $370 \mathrm{nt}$ ). The phylogenetic tree of nifH-derived amino acid sequences was compared to the phylogenetic tree of rrs sequences. All Paenibacillus nifH sequences formed a coherent cluster distinct from that of related nitrogen-fixing anaerobic clostridia and Grampositive high-G+C-content frankiae. The nifH gene was neither detected in the B. circulans type strain (ATCC 4513') nor in the type strains of Bacillus subtilis, Bacillus cereus, Bacillus alcalophilus, Bacillus simplex, Brevibacillus brevis and Paenibacillus validus. Accordingly, nitrogen fixation among aerobic endosporeforming Firmicutes seems to be restricted to a subset of species in the genus Paenibacillus.
\end{abstract}

Keywords: Paenibacillus, Bacillus, phylogeny, rDNA and nifH sequencing, nitrogen fixation

\section{INTRODUCTION}

Comparative rrs (16S rDNA) sequence analysis has demonstrated that the genus Bacillus consists of at least five monophyletic clusters (Ash et al., 1991). The rRNA group 1 (Bacillus sensu stricto) of aerobic, endospore-forming bacilli includes type species Bacillus subtilis. The species Bacillus pantothenticus initially included in rRNA group 1 (Ash et al., 1991) has been recently renamed Virgibacillus pantothenticus (Heyndrickx et al., 1998). The rRNA group 3 (Ash et al., 1991) which includes the species Bacillus azotofixans, Bacillus polymyxa, Bacillus macerans, Bacillus amylolyticus, Bacillus macquariensis, Bacillus pabuli, Bacillus pulvifaciens, Bacillus larvae, Bacillus alvei and Bacillus gordonae has been transferred to the new genus Paenibacillus (Ash et al., 1993). Heyndrickx et

Abbreviation: ARA, acetylene-reduction assay.

The EMBL accession numbers for the rrs and nifH sequences determined in this paper are AJ223987-AJ223997. al. (1995) showed that the species Paenibacillus gordonae and Paenibacillus validus form a homogeneous group leading to the emended description of $P$. validus. Paenibacillus larvae and Paenibacillus pulvifaciens, have been combined into P. larvae as Paenibacillus larvae subsp. larvae and Paenibacillus larvae subsp. pulvifaciens, respectively (Heyndrickx et al., 1996a). Bacillus lautus and Bacillus peoriae were reclassified as Paenibacillus lautus and Paenibacillus peoriae, respectively (Heyndrickx et al., 1996b). Recently, further Bacillus species, Bacillus alginolyticus, Bacillus chondroitinus, Bacillus curdlanolyticus, Bacillus glucanolyticus, Bacillus kobensis and Bacillus thiaminolyticus, have also been transferred to the genus Paenibacillus (Shida et al., 1997a, b).

Three of the former Bacillus species, Paenibacillus azotofixans, Paenibacillus polymyxa and Paenibacillus macerans, are dinitrogen-fixers, and they form a monophyletic cluster in the genus Paenibacillus (Ash et al., 1993). Paenibacillus durum, which is also a nitrogen-fixing species, has recently been grouped into 
P. azotofixans (Rosado et al., 1997). On the other hand, Bacillus circulans which includes some nitrogenfixing strains (belonging to B. circulans group 2) (Priest et al., 1981), remained in the genus Bacillus on the basis of the rrs sequence data obtained for the $B$. circulans type strain, ATCC $4513^{\mathrm{T}}$ (Ash et al., 1993).

In order to determine the taxonomic position of nitrogen-fixing strains which had been isolated from the rhizosphere of wheat (TOD45) and maize (RSA19) and identified as $B$. circulans (group 2) by phenotypic characterization (API 50CH) (Berge et al., 1991), their rrs gene was sequenced. Since nitrogen fixation among aerobic endospore-forming bacilli is a physiological character of major importance both for taxonomic and phylogenetic purposes and for ecological assessment, the type strains of some representative species of the genera Bacillus and Paenibacillus were analysed for nitrogenase activity (acetylene-reduction assay, ARA) and for the presence of the nifH gene.

\section{METHODS}

Bacterial strains and growth conditions. Strains used in this study are listed in Table 1. Strains PMD230 (Mavingui et al., 1992), CF43 (Heulin et al., 1994) and TOD45 were isolated from the rhizosphere of wheat, and strain RSA19 was isolated from the rhizosphere of maize (Berge et al., 1991). Strains were grown in LB medium $\left(1^{-1}\right.$ distilled water: $10 \mathrm{~g}$ tryptone, $5 \mathrm{~g}$ yeast extract and $5 \mathrm{~g} \mathrm{NaCl}$ ) at $28^{\circ} \mathrm{C}$, for $48 \mathrm{~h}$ for DNA extraction, and up to an $\mathrm{OD}_{590}$ of 0.5 for PCR amplification.

Phenotypic characters. All strains studied were checked microscopically and by colony morphology. Biochemical identification was carried out using both the API $50 \mathrm{CH}$ (bioMérieux; http://www.biomerieux.fr/) and Biolog systems (http://www.biolog.com/).

Amplification and sequencing of rrs genes. Ten microlitres of water-washed suspensions $\left(\mathrm{OD}_{590} 0.5\right)$ of the cultures were used for PCR amplification using a pair of universal primers (FGP5-255 and FGPS1509'-153; Normand et al., 1995) corresponding to positions 5-24 and 1524-1540 of the Escherichia coli rrs sequence (GenBank accession no. J01859). The PCR products were purified on a $1 \%(\mathrm{w} / \mathrm{v})$ low-melting-point-agarose gel (Bio-Rad). They were sequenced directly according to Anderson et al. (1992) with the Genomyx system (Beckman; http:// www.beckman.com/), using primers described previously (Normand et al., 1996).

Amplification and sequencing of nifH genes. A $370 \mathrm{bp}$

\section{Table 1. Bacterial strains used, rrs and nifH sequence accession numbers and nitrogenase activities}

EMBL accession numbers in bold are for sequences determined in this study.

\begin{tabular}{|c|c|c|c|c|}
\hline \multirow[t]{2}{*}{ Bacterial species } & \multirow[t]{2}{*}{ Strain } & \multicolumn{2}{|c|}{ Sequence accession no. } & \multirow{2}{*}{$\begin{array}{l}\text { Nitrogenase activity* } \\
\quad(\text { mean } \pm \text { SD })\end{array}$} \\
\hline & & $r r s$ & nifH & \\
\hline Paenibacillus azotofixans & ATCC $35681^{\mathrm{T}}$ & X60608 & U23649 & $9 \cdot 5 \pm 1 \cdot 6$ \\
\hline Paenibacillus azotofixans & LMG $14658^{\mathrm{T}}$ & & AJ223993 & $7 \cdot 1 \pm 1 \cdot 3$ \\
\hline Paenibacillus macerans & ATCC $8244^{\mathrm{T}}$ & X57306 & AJ223994 & $2 \cdot 1 \pm 1 \cdot 0$ \\
\hline Paenibacillus sp. & RSA19 & AJ223987 & AJ223995 & $1 \cdot 3 \pm 0 \cdot 3$ \\
\hline Paenibacillus polymyxa & PMD230 & AJ223988 & AJ223996 & $0 \cdot 8 \pm 0 \cdot 3$ \\
\hline Paenibacillus polymyxa & CF43 & AJ223989 & & $0 \cdot 7 \pm 0 \cdot 1$ \\
\hline Paenibacillus larvae & LMG $9820^{\mathrm{T}}$ & X60619 & & Weak \\
\hline Paenibacillus amylolyticus & LMG $11153^{\mathrm{T}}$ & D85396 & & Weak \\
\hline Paenibacillus lautus & LMG $11157^{\mathrm{T}}$ & D78473 & & Weak \\
\hline Paenibacillus pabuli & LMG $11158^{\mathrm{T}}$ & $\mathrm{X} 60625$ & & Weak \\
\hline Paenibacillus polymyxa & $\operatorname{ATCC} 842^{\mathrm{T}}$ & $\mathrm{X} 60632$ & AJ223997 & Weak \\
\hline Paenibacillus polymyxa & LMG $13294^{\mathrm{T}}$ & & & Weak \\
\hline Paenibacillus peoriae & LMG $14832^{\mathrm{T}}$ & D78476 & & Weak \\
\hline Paenibacillus sp. & TOD45 & AJ223990 & AJ223992 & Weak \\
\hline Paenibacillus validus & LMG $11161^{\mathrm{T}}$ & D78320 & & Negative \\
\hline Paenibacillus apiarius & LMG $17433^{\mathrm{T}}$ & U49247 & & Negative \\
\hline Paenibacillus alvei & LMG $13253^{\mathrm{T}}$ & X60604 & & Negative \\
\hline Bacillus longisporus & LMG $13275^{\mathrm{T}}$ & AJ223991 & & Negative \\
\hline Bacillus alcalophilus & LMG $7120^{\mathrm{T}}$ & & & Negative \\
\hline Bacillus cereus & LMG $6923^{\mathrm{T}}$ & D16266 & & Negative \\
\hline Bacillus circulans & $\operatorname{ATCC} 4513^{\mathrm{T}}$ & X60613 & & Negative \\
\hline Bacillus subtilis & LMG $7135^{\mathrm{T}}$ & X60646 & & Negative \\
\hline Bacillus simplex & LMG $11160^{\mathrm{T}}$ & & & Negative \\
\hline Brevibacillus brevis & LMG $7123^{\mathrm{T}}$ & X60612 & & Negative \\
\hline
\end{tabular}

* ARA results in $\mu \mathrm{mol} \mathrm{C}_{2} \mathrm{H}_{4}$ produced per tube measured after $4 \mathrm{~d}$ incubation under $2 \% \mathrm{C}_{2} \mathrm{H}_{2}$; weak result, values ranging from 30 to $150 \mathrm{nmol} \mathrm{C}_{2} \mathrm{H}_{4}$ per tube; negative result, no difference compared with negative control. 
fragment of the nifH gene corresponding to positions 111 and 483 of the Bradyrhizobium japonicum nifH sequence (GenBank accession no. E01169) was amplified using the following primers: forward 5'-GGAATTCTGTGATCCTAAAGCTGA-3' and reverse 5'-AGCATACATTGCCATCATTTCACC-3' (modified from Zehr et al., 1995). Four primers were used in the sequencing reaction of the $370 \mathrm{bp}$ of nifH gene: the two primers used for amplification and two internal primers. The purification and sequencing steps were the same as described above for the rrs gene.

Acetylene-reduction tests. ARA was performed as described by Omar et al. (1989). Briefly, strains were grown for $48 \mathrm{~h}$ on solid Watanabe's modified medium (Omar et al., 1989) containing $5 \mathrm{~g} \mathrm{l}^{-1}$ glucose, sucrose, starch and mannitol. They were incubated under $2 \%(\mathrm{v} / \mathrm{v})$ acetylene/air for $4 \mathrm{~d}$, and then analysed for ethylene production by GC (Omar et al., 1989).

Data analysis. Sequences were aligned using CLUSTAL V (Higgins \& Sharp, 1988). Indel-containing regions were excluded from the analysis. Matrix pairwise comparisons were corrected for multiple base substitutions by the twoparameter method of Kimura (1980). Phylogenetic trees were constructed by the neighbour-joining (Saitou \& Nei, 1987) and parsimony (Kluge \& Farris, 1969) methods. A bootstrap confidence analysis was performed on 1000 replicates to determine the reliability of the distance tree topologies obtained (Felsenstein, 1985). Graphic representation of the resulting trees was made using the NJPlot software (Perrière \& Gouy, 1996).

\section{RESULTS AND DISCUSSION}

Strains PMD230 and CF43 were identified as $P$. polymyxa and strains RSA19 and TOD45 as $B$. circulans by both API $50 \mathrm{CH}$ and Biolog systems.

The phenotypic identification of strains PMD230 and CF43 as $P$. polymyxa was confirmed by results from rrs sequencing (Fig. 1). However, the phenotypic identification of strains RSA19 and TOD45 as $B$. circulans (group 2) using the API 50CH and Biolog systems was not in accordance with the results from the comparison of the rrs sequences (Fig. 1). It can thus be inferred that these two strains constitute a new species yet to be described which will probably also include other strains formerly classified into $B$. circulans group 2.

These two rhizosphere strains were found to form a monophyletic cluster with $P$. azotofixans, $P$. polymyxa and $P$. macerans and with $P$. peoriae (Fig. 1). Emendation of $B$. circulans started recently with the description of Paenibacillus illinoisensis (Shida et al., 1997b), another species for which nitrogen fixation capacity still has to be checked. On the basis of our data from rrs sequencing, 'Bacillus longisporus' would also have to be transferred to the genus Paenibacillus. This last species is taxonomically closely related to P. amylolyticus and Paenibacillus pabuli (Fig. 1).

When this work was started, the only nifH gene sequence available in the genus Paenibacillus was that of P. azotofixans (Zehr et al., 1995). In the present study, a nif $H$ amplicon of 370 nucleotides in the $P$. polymyxa and $P$. macerans type strains was detected, as well as in strains RSA19, CF43 and PMD230 (Table 1). For some other Paenibacillus strains, a weak amplicon was obtained using nifH primers (data not shown), but the sequences obtained were completely different from the expected nif $H$ sequence. This illustrates that obtaining an amplicon with nifH primers is not enough to infer the presence of a nif gene, and confirmation by hybridization or sequencing is thus necessary.

Although a nifH gene was detected in the $P$. polymyxa type strain, ATCC $842^{\mathrm{T}}$ (as well as LMG $13294^{\mathrm{T}}$ ), and in strain TOD45 (Fig. 2), only weak nitrogenase activity was measured (Table 1). Nitrogen fixation by the $P$. polymyxa type strain was determined by measuring nitrogen gains through micro-Kjeldahl analyses, while acetylene-reduction activity has never yielded positive results (Rhodes-Roberts, 1981). Rhodes-Roberts (1981) concluded that the P. polymyxa type strain is nitrogen-fixing, and that suitable conditions for demonstrating acetylene reduction remain to be found. The present study reinforces this conclusion.

Weak acetylene-reduction activity was detected for the type strains of $P$. larvae, $P$. amylolyticus, $P$. lautus, Paenibacillus macquariensis and $P$. peoriae, but no detectable nifH amplicon. A similar case was reported for Streptomyces thermoautotrophicus (Gadkari et al., 1992). Conclusions on whether nitrogen fixation occurs in a bacterial strain should hence be drawn from both a positive nitrogenase activity test (acetylene-reduction assay, micro-Kjeldahl or ${ }^{15} \mathrm{~N}$ uptake analyses), and by sequencing an amplicon from a conserved structural nif gene such as nifH.

All Paenibacillus nifH sequences formed a coherent cluster together with the sequence of $P$. azotofixans defined by Zehr et al. (1995), which was different from those of the closely related nitrogen-fixing anaerobic genus Clostridium and the Gram-positive high-G $+\mathrm{C}$ content genus Frankia. Our data reinforce the assumption that nifH genes of aerobic genera (Paenibacillus, cyanobacteria, actinomycetes, proteobacteria) and anaerobic genera (Clostridium, Desulfovibrio, Chromatium), are deeply divergent, as previously claimed by Chien \& Zinder $(1994,1996)$. These authors showed that the described nifHDKE sequences could be distributed into four clusters (aerobes, anaerobes, alternative nitrogenase and archaea). The present study confirms that all the tested nitrogenfixing members of the Bacillaceae belong to the group of aerobic nitrogen-fixers and are away from the phyletically related genus Clostridium. It highlights the fact that genes encoding non-ubiquitous and nonessential functions are poor phylogenetic markers because of the divergent selection pressures exerted on them (Woese, 1987).

The nifH phylogenetic tree (Fig. 2) was compared to 


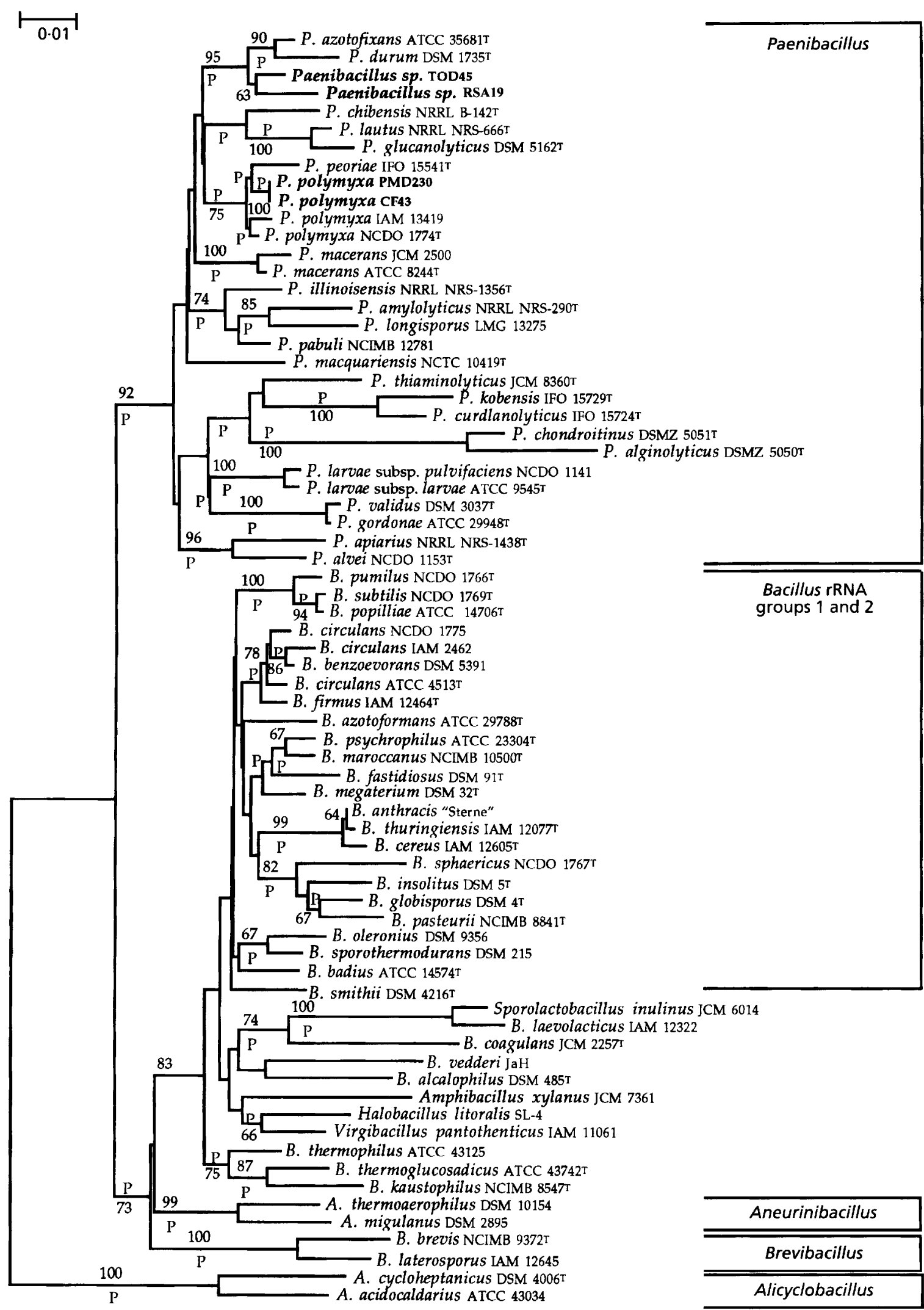

Fig. 1. Phylogeny of rrs genes of selected Bacillaceae species and strains analysed by the neighbour-joining method. The percentage of 1000 bootstrap replicates higher than $60 \%$ is indicated above nodes, and those supported by parsimony analysis are indicated by a ' $P$ ' below it. Almost complete sequences were used. Scale bar represents 0.01 substitutions per site. 


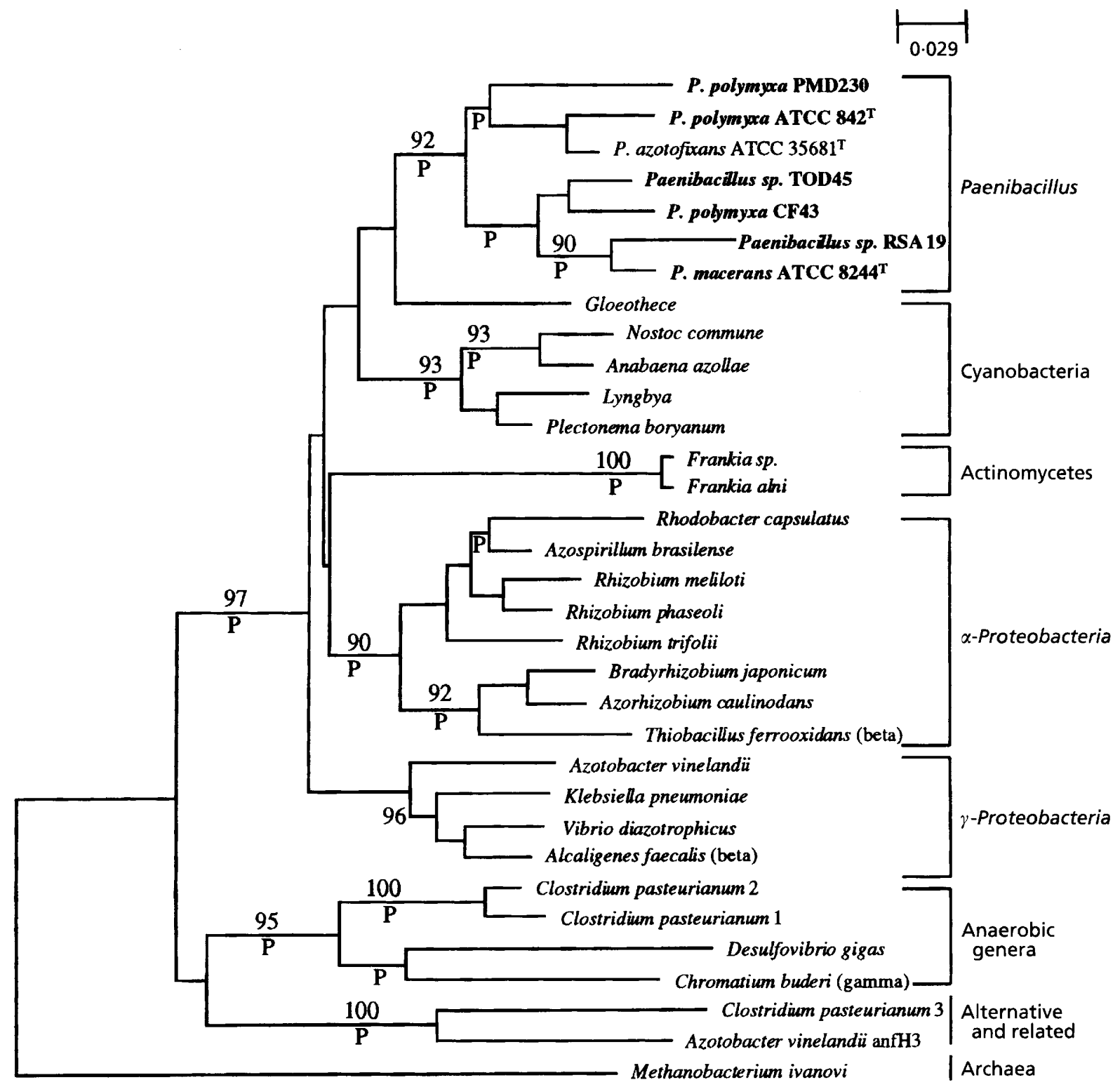

Fig. 2. Phylogeny of a fragment of nifH amino acid deduced sequences analysed by the neighbour-joining method. The percentage of 1000 bootstrap replicates that support each topological element by more than $90 \%$ is indicated above nodes, and those supported by parsimony analysis are indicated by a ' $P$ ' below. Only partial sequences ( 99 aa) of the nifH gene of Paenibacillus species were determined in the present study. Scale bar represents 0.029 substitutions per site.

that of the rrs gene. Differences in the topology of both trees should not be regarded as evidence of lateral transfer events. Presumably they originate rather from the short length, and the high sequence conservation of the studied nifH gene fragment, which reduces the resolving power of the analysis. A longer fragment could not be obtained in the nifH gene since it has not yet been sequenced completely for a member of the Bacillaceae, and appropriate primers do not yet exist in the less conserved C-terminal part of the gene. A combination of nifH and nifD primers might be used. A similar strategy was performed in the high-resolution phylogenetic analysis of Frankia (Cournoyer $e t$ al., 1993; Nalin et al., 1995).
Neither in the $B$. circulans type strain, ATCC $4513^{\mathrm{T}}$, nor in the type strains of B. subtilis, B. cereus, B. alvei, Bacillus alcalophilus, Bacillus simplex, Brevibacillus brevis and Paenibacillus validus could a nifH amplicon be detected or ARA activity be demonstrated. This does not exclude the possibility that nitrogen-fixing Bacillus strains will not be isolated in the future, but nitrogen fixation should be assessed more systematically. This could allow more comprehensive conclusions to be drawn on the distribution of nitrogen fixation in the Firmicutes.

Even if our investigations were performed with only a part of the described Bacillus species, our results 
suggest that nitrogen fixation among aerobic endospore-forming bacilli is restricted to the genus Paenibacillus. In contrast, in proteobacteria and cyanobacteria nitrogen-fixing taxa are interspersed with nonnitrogen-fixing ones. The situation in the Bacillaceae would be in accordance with that found in the other Firmicutes where nitrogen-fixers are rare and form the monophyletic taxa Frankia and Clostridium.

\section{REFERENCES}

Anderson, R. D., Bao, C.-Y., Minnick, D. T., Viegel, M. \& Sedwick, W. D. (1992). Optimization of double-stranded DNA sequencing for polymerase chain reaction products. USB Editorial Comments 19, 39-40, 57-58.

Ash, C., Farrow, J. A. E., Wallbanks, S. \& Collins, M. D. (1991). Phylogenetic heterogeneity of the genus Bacillus revealed by comparative analysis of small-subunit-ribosomal RNA sequences. Lett Appl Microbiol 13, 202-206.

Ash, C., Priest, F. G. \& Collins, M. D. (1993). Molecular identification of rRNA group 3 bacilli (Ash, Farrow, Wallbanks \& Collins) using PCR probe test. Antonie Leeuwenhoek 64,

Berge, O., Heulin, T. \& Balandreau, J. (1991). Diversity of diazotroph populations in the rhizosphere of maize (Zea mays L.) growing on different French soils. Biol Fertil Soils 11, $210-215$.

Chien, Y.-T. \& Zinder, S. H. (1994). Cloning, DNA sequencing, and characterization of a nifD-homologous gene from the archaeon Methanosarcina barkeri 227 which resembles nifD1 from the eubacterium Clostridium pasteurianum. $J$ Bacteriol 176, 6590-6598.

Chien, Y.-T. \& Zinder, S. H. (1996). Cloning, functional organization, transcript studies, and phylogenetic analysis of the complete nitrogenase structural genes (nifHDK2) and associated genes in the archaeon Methanosarcina barkeri 227. $J$ Bacteriol 178, 143-148.

Cournoyer, B., Gouy, M. \& Normand, P. (1993). Phylogeny of the symbiotic actinomycetes of the genus Frankia matches hostplant infection process. Mol Biol Evol 10, 1303-1316.

Felsenstein, J. (1985). Confidence limits on phylogenies: an approach using the bootstrap. Evolution 39, 783-791.

Gadkari, D., Morsdorf, G. \& Meyer, O. (1992). Chemolithotrophic assimilation of dinitrogen by Streptomyces thermoautotrophicus UBT1: ideintification of an unusual $\mathrm{N}_{2}$-fixing system. J Bacteriol 174, 6840-6843.

Heulin, T., Berge, O., Mavingui, P., Gouzou, L., Hebbar, K. P. \& Balandreau, J. (1994). Bacillus polymyxa and Rahnella aquatilis, the dominant $\mathrm{N}_{2}$-fixing bacteria associated with wheat rhizosphere in French soils. Eur J Soil Biol 30, 35-42.

Heyndrickx, M., Vandemeulebroecke, K., Scheldeman, P. \& 7 other authors (1995). Paenibacillus (formerly Bacillus) gordonae (Pichinoty et al., 1986) Ash et al. 1994 is a later subjective synonym of Paenibacillus (formerly Bacillus) validus (Nakamura et al. 1984) Ash et al. 1994: emended description of $P$. validus. Int J Syst Bacteriol 45, 661-669.

Heyndrickx, M., Vandemeulebroecke, K., Hoste, B., Janssen, P., Kersters, K., De Vos, P., Logan, N. A., Ali, N. \& Berkeley, R. C. W. (1996a). Reclassification of Paenibacillus (formerly Bacillus) pulvifaciens (Nakamura 1984) Ash et al. 1994, a later subjective synonym of Paenibacillus (formerly Bacillus) larvae (White
1906) Ash et al. 1994, as a subspecies of $P$. larvae, with emended descriptions of $P$. larvae as $P$. larvae subsp. larvae and $P$. larvae subsp. pulvifaciens. Int J Syst Bacteriol 46, 270-279.

Heyndrickx, M., Vandemeulebroecke, K., Scheldeman, P., Kersters, K., De Vos, P., Logan, N. A., Aziz, A. M., Ali, N. \& Berkeley, R. C. W. (1996b). A polyphasic reassessment of the genus Paenibacillus, reclassification of Bacillus lautus (Nakamura 1984) as Paenibacillus lautus comb. nov. and of Bacillus peoriae (Montefusco et al. 1993) as Paenibacillus peoriae comb. nov., and emended descriptions of $P$. lautus and of $P$. peoriae. Int J Syst Bacteriol 46, 988-1003.

Heyndrickx, M., Lebbe, L., Kersters, K., De Vos, P., Forsyth, G. \& Logan, N. A. (1998). Virgibacillus: a new genus to accomodate Bacillus pantothenticus (Proom \& Knight 1950). Emended description of Virgibacillus pantothenticus. Int $J$ Syst Bacteriol 48, 99-106.

Higgins, D. G. \& Sharp, P. M. (1988). CluSTAL: a package for performing multiple sequence alignments on a microcomputer. Gene 73, 237-244.

Kimura, M. (1980). A simple method for estimating evolutionary rates of base substitutions through comparative studies of nucleotide sequences. $J$ Mol Evol 16, 111-120.

Kluge, A. G. \& Farris, J. S. (1969). Quantitative phyletics and the evolution of anurans. Syst Zool 18, 1-32.

Mavingui, P., Laguerre, G., Berge, O. \& Heulin, T. (1992). Genetic and phenotypic diversity of Bacillus polymyxa in soil and in the wheat rhizosphere. Appl Environ Microbiol 58, 1894-1903.

Nalin, R., Domenach, A.-M. \& Normand, P. (1995). Characterization of an intergenic spacer between nifD and nifK in Frankia. Mol Ecol 4, 483-491.

Normand, P. (1995). Utilisation des séquences $16 \mathrm{~S}$ pour le positionnement phylétique d'un organisme inconnu. Océanis

Normand, P., Orso, S., Cournoyer, B., Jeannin, P., Chapelon, C., Dawson, J., Evtushenko, L. \& Misra, A. K. (1996). Molecular phylogeny of the genus Frankia and related genera and emendation of family Frankiaceae. Int J Syst Bacteriol 46, 1-9.

Omar, A. M. N., Richard, C., Weinhard, P. \& Balandreau, J. (1989). Using the spermosphere model technique to describe the dominant nitrogen-fixing microflora associated with wetland rice in two Egyptian soils. Biol Fertil Soils 7, 158-163.

Perrière, G. \& Gouy, M. (1996). WWW-Query: an on-line retrieval system for biological sequence banks. Biochimie $\mathbf{7 8}$, 364-369; http://pbil.univ-lyon1.fr/.

Priest, F. G., Goodfellow, M. \& Todd, C. (1981). The genus Bacillus: a numerical analysis. In The Aerobic EndosporeForming Bacteria. Classification and Identification, pp. 91-103. Edited by R. C. W. Berkeley \& M. Goodfellow. London: Academic Press.

Rhodes-Roberts, M. (1981). The taxonomy of some nitrogenfixing Bacillus species with special reference to nitrogen fixation. In The Aerobic Endospore-Forming Bacteria. Classification and Identification, pp. 315-335. Edited by R. C. W. Berkeley \& M. Goodfellow. London: Academic Press.

Rosado, A. S., van Elsas, J. D. \& Seldin, L. (1997). Reclassification of Paenibacillus durum (formerly Clostridium durum Smith \& Cato 1974) Collins et al., 1994 as a member of the species $P$. azotofixans (formerly Bacillus azotofixans Seldin et al., 1984) Ash et al. (1994). Int J Syst Bacteriol 47, 569-572.

Saitou, N. \& Nei, M. (1987). The neighbour-joining method: a new method for reconstructing phylogenetic trees. Mol Biol Evol 4, 406-425. 
Shida, O., Takagi, H., Kadowaki, K., Nakamura, L. K. \& Komagata, K. (1997a). Transfer of Bacillus alginolyticus, Bacillus chondroitinus, Bacillus curdlanolyticus, Bacillus kobensis, and Bacillus thiaminolyticus to the genus Paenibacillus and emended description of the genus Paenibacillus. Int J Syst Bacteriol 47, 289-298.

Shida, O., Takagi, H., Kadowaki, K., Nakamura, L. K. \& Komagata, K. (1997b). Emended description of Paenibacillus amylolyticus and description of Paenibacillus illinoisensis sp. nov. and Paenibacillus chibensis sp. nov. Int J Syst Bacteriol 47, 299-306. Woese, C. R. (1987). Bacterial evolution. Microbiol Rev 51, 221-271.

Zehr, J. P., Mellon, M., Braun, S., Litaker, W., Steppe, T. \& Paerl, H. W. (1995). Diversity of heterotrophic nitrogen fixation genes in a marine cyanobacterial mat. Appl Environ Microbiol 61, 2527-2532. 